\title{
Early Motherhood and Contraceptive Use among Adolescents: A Study from Rajshahi District of Bangladesh
}

\author{
Rahman $\mathbf{M M}^{1}$ \\ ${ }^{1}$ Md. Mosiur Rahman, Department of Population Science and Human Resource Development, University of Rajshahi, \\ Rajshahi-6205, Bangladesh.
}

Address for correspondence: E-mail: swaponru_2000@yahoo.com

\begin{abstract}
Introduction: This paper employs various statistical methods to identify the factors associated with age at first motherhood and contraception use among the adolescence mothers in Rajshahi district of Bangladesh. Methods: To meets the objectives this study utilizes information from 1000 married adolescents of Rajshahi district within the age span (15-19 years). Results: We have observed adolescents mean age at first marriage and birth to be 15.0 and 16.4 years. This study reveals that the education, place of residence, occupation of husband and religion played the greatest roles on adolescent's age at first motherhood. The analysis shows that, use of contraceptive among the adolescent's was still very low. Slightly 56.7 per cent of the married adolescents were currently using any method of contraception. Among the factors determining contraceptive use among adolescents, education, visits of family planning workers and place of residence appears to be the most significant and positively associated with contraceptive use. Conclusions: The results indicate several policy options: (1) government has to take initial steps to strictly prohibit the early marriage with the proper application of existing law that would directly or indirectly rise the age at first birth among the adolescence; (2) programmes that encourage postponement of first birth after marriage through adoption of temporary contraceptive methods should be considered seriously ; (3) provide adolescents with information on the availability of family planning methods and their effectiveness; (4) increase the number of visits by family planning workers and their counseling about family planning methods help to motivate adolescents to accept family planning methods and use them effectively and (5)emphasize adolescents education to make a lasting impact on overall health of the adolescent mothers.
\end{abstract}

Key words: Adolescence, age specific live birth, contraception

\section{Introduction}

A dolescents are the young population aged $10-19$ years, a vital population segment, making up 25 percents of the Bangladeshi population ${ }^{1}$. Adolescence is an important period, in which there is a rapid growth both physically and mentally. Eventhough adolescence starts earlier than fifteen years of age, the childbearing group (15-19 years) amount to 15 percent of all Bangladeshi women ${ }^{2}$. This period of adolescence is characterized by high risk for early and unwanted sexual activity forced marriage, and early pregnancy related events.
Although teenage fertility rates were declining throughout the late 1960s and early 1970s, their reproductive behavior emerged as a major concern in many developing countries like Bangladesh. In Bangladesh, where more than one fifth of adolescence had a first birth before age fifteen, nearly two thirds before age eighteen and 80.0 percent by age of twenty years ${ }^{3}$. Child bearing as crucial period of human development might have serious consequences on these young mothers. It can limit educational attainment, restrict the skills of young mothers acquire for the work force, 
limit their capacity to support themselves financially, negatively affect their health, and reduce their quality of life. However, adolescent women who become a parent in adolescents are at greater risk of social and economic disadvantages throughout their lives than those who delay child bearing until their twenties. They are less likely to complete their education, to be employed, to earn high wages, and to be happily married. They are more likely to have larger families especially in a country of low contraceptive prevalence like Bangladesh ${ }^{4}$. The ability of young mothers to support themselves and their children is affected by the employment opportunities available to them. These opportunities, in turn, are largely determined by the qualifications that young mothers bring to the market. It seems reasonable to assume that caring for young children will conflict with and possibly reduce a woman's investment of time and effort in primary- school completion, college attendance, post-secondary training, and early work experience. If reductions in these early investments occur, they are likely to have profound, long-term consequences for the earnings and employability of the mother and, hence, for the economic well being of both the mother and her children. It was found in the 1999-2000 Bangladesh Demographic Health Survey (BDHS) survey that a high proportion of young women (15-19 years) had unplanned births - either not wanted at the time of the birth or not wanted at all (27 percent). Faced with an unplanned pregnancy, some young women may turn to illegal abortion since abortion is prohibited in Bangladesh. For these reasons, it is important to separate adolescents from other groups in the study of child bearing.

In Bangladesh, adolescent women in marital status are generally aware of contraceptive methods but very few use them. For example in the 1999-2000 BDHS, it was found that 99.9 percent of women at the age of $15-19$ have heard of at least one method of family planning, but 61.9 percent are not using any contraception. This indicates that adolescents are aware of modern contraceptive methods but in fact, very few use them. This study examines the adolescent's age at first motherhood with emphasis on differentials in adolescence use of contraceptives.

\section{Methodology}

The data were collected from a field survey conducted under the project of UNFPA entitled "Strengthening the Department of Population Science and Human Resource Development" in the district of Rajshahi of Bangladesh. These data were collected from both rural and urban residential areas of Rajshahi district. Information was collected from 1000 married adolescents' women by interview method of both rural and urban areas. Respondents were selected by purposive sampling technique. Rural respondents were from Mohanpur thana of Rajshahi district and the urban respondents were from three district wards of Rajshahi City Corporation. Percentage distribution and the average value are used to investigate the overview picture of the respondents for some selected sociodemographic characteristics. Both Multiple and logistic regression analysis is used to single out the net effects of some socio-demographic variables.

\section{Results}

\section{Adolescents Age at First Motherhood and Child bearing}

Adolescents engage in marital union early and give earlier birth. According to our study adolescents who were aged 15 get married at age 14 and have first birth when they were 15 years of age (Fig-1).

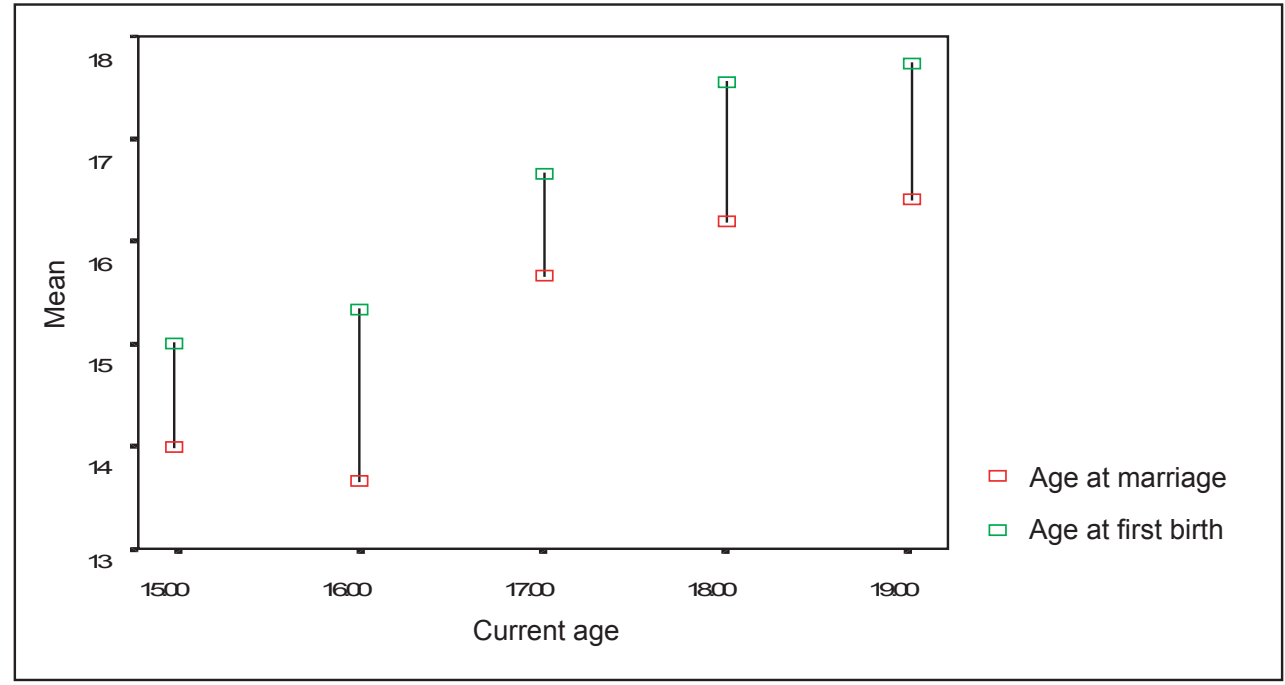

Fig. 1: Adolescents' age at first marriage and birth in single years 
Table 1: Adolescent's Mean Age at First Marriage and Birth

\begin{tabular}{|l|c|c|c|c|}
\hline \multirow{2}{*}{} & \multicolumn{4}{|c|}{ Age group } \\
\cline { 2 - 5 } & $\mathbf{1 5 - 1 6}$ & $\mathbf{1 7 - 1 8}$ & $\mathbf{1 8 - 1 9}$ & $\mathbf{1 5 - 1 9}$ \\
\hline MAFM & 13.7 & 14.9 & 15.1 & 15.0 \\
\hline MAFB & 15.0 & 16.5 & 17.5 & 16.4 \\
\hline
\end{tabular}

Note: MAFB (Mean age at first birth), MAFM (Mean age first marriage)

Table 2: Age specific Live Birth of the Adolescents.

\begin{tabular}{|c|c|c|c|}
\hline $\begin{array}{c}\text { Age group } \\
\mathbf{( 1 )}\end{array}$ & $\begin{array}{c}\text { Average male live birth } \\
\mathbf{( 2 )}\end{array}$ & $\begin{array}{c}\text { Average female live birth } \\
\mathbf{( 3 )}\end{array}$ & $\begin{array}{c}\text { Ratio of average f male } \\
\text { and female live birth } \\
\mathbf{( 4 )}=\mathbf{( 2 ) / ( 3 )}\end{array}$ \\
\hline $15-16$ & .25 & .50 & .50 \\
\hline $17-18$ & .58 & .42 & 1.38 \\
\hline $18-19$ & .59 & .44 & 1.34 \\
\hline $15-19$ & .57 & .44 & 1.29 \\
\hline
\end{tabular}

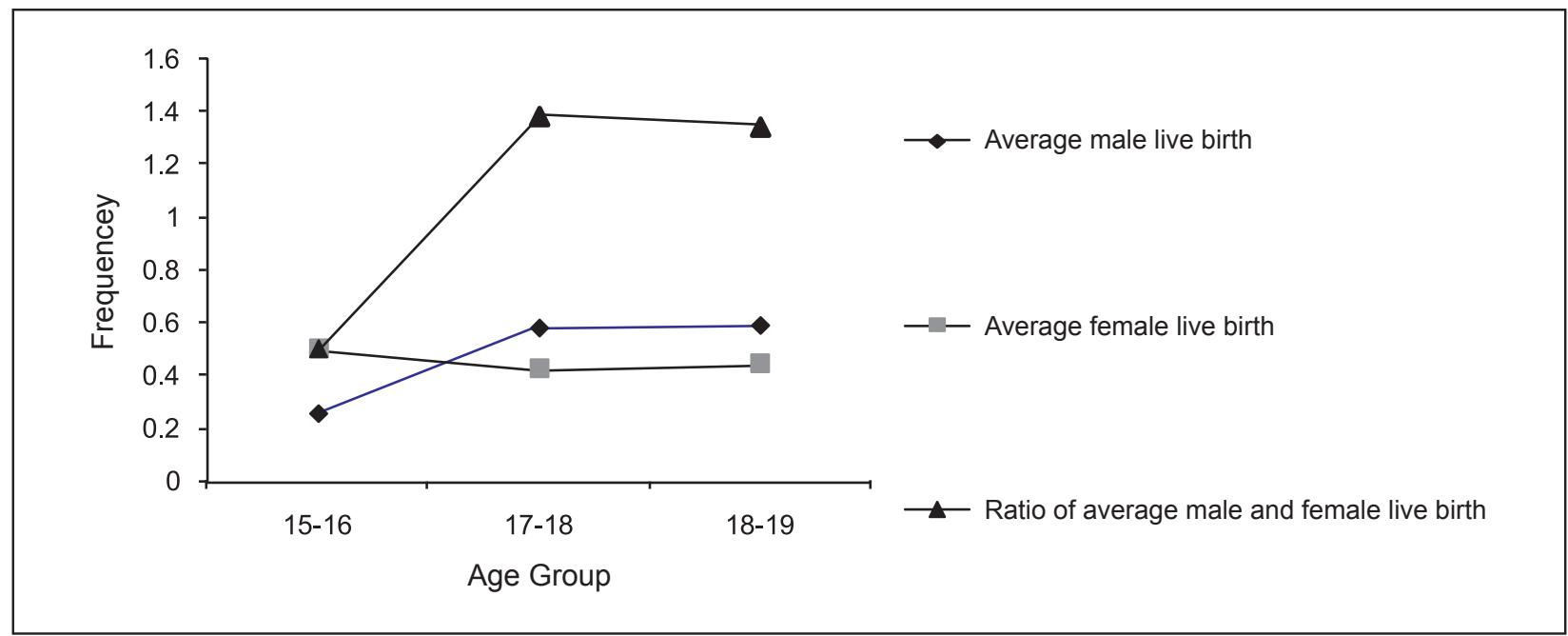

Fig. 2: Age specific live birth per adolescents

Table -1 shows that the average age at first marriage of the adolescents is 15.0 years and the average age at which adolescent bear their first child is about 16.4 years. Further, the age specific live birth per adolescent's women gives us a better understanding of adolescent's childbearing of our study area

From Table: 2 we see that the average male live birth per adolescent's women is higher than the average female live birth. We also observed that the ratio of average male and female live birth for the adolescent's is 1.29 the same result is also observed in Fig-2.

\section{Socio-economic Factors Associated with Adolescent's Age at First Motherhood}

From Table-3 we see that adolescents in rural areas have a lower mean age at first birth than those in urban areas, this urban-rural difference might be attributed to many factors, e.g. education. However, it is believed that women's mean age at first birth may be rooted in the behavior acquired during childhood. Since modernization usually starts in urban areas before spreading its influence gradually into the rural areas, in a transitional society such as Bangladesh, one would expect the patterns of early childbearing to be more pronounced in rural areas than in urban areas ${ }^{5}$. 
Table 3: Adolescent's Mean Age at First Motherhood by Selected Socio-economic Characteristics and Current Age.

\begin{tabular}{|c|c|c|c|c|}
\hline \multirow{2}{*}{ Characteristics } & \multicolumn{4}{|c|}{ Current age } \\
\hline & $15-16$ & $17-18$ & $18-19$ & $15-19$ \\
\hline $\begin{array}{l}\text { Place of residence } \\
\text { Urban } \\
\text { Rural }\end{array}$ & $\begin{array}{l}15.0 \\
15.0\end{array}$ & $\begin{array}{l}16.4 \\
16.1\end{array}$ & $\begin{array}{l}18.0 \\
16.5\end{array}$ & $\begin{array}{l}16.5 \\
16.3\end{array}$ \\
\hline $\begin{array}{l}\text { Head of household } \\
\text { Male } \\
\text { Female }\end{array}$ & $\begin{array}{l}16.0 \\
14.0\end{array}$ & $\begin{array}{l}16.5 \\
15.4\end{array}$ & $\begin{array}{l}16.8 \\
16.5\end{array}$ & $\begin{array}{l}16.6 \\
15.5\end{array}$ \\
\hline $\begin{array}{l}\text { Religion } \\
\text { Muslims } \\
\text { Non- Muslims }\end{array}$ & $\begin{array}{c}15.0 \\
--\end{array}$ & $\begin{array}{l}16.4 \\
15.0\end{array}$ & $\begin{array}{l}16.8 \\
16.0\end{array}$ & $\begin{array}{l}16.5 \\
15.5\end{array}$ \\
\hline $\begin{array}{l}\text { Education of respondents } \\
\text { No education } \\
\text { Primary incomplete } \\
\text { Primary complete } \\
\text { Secondary and higher } \\
\text { education }\end{array}$ & $\begin{array}{c}14.6 \\
-- \\
16.0 \\
--\end{array}$ & $\begin{array}{l}16.1 \\
17.0 \\
16.3 \\
17.0\end{array}$ & $\begin{array}{l}17.0 \\
15.7 \\
16.6 \\
18.0\end{array}$ & $\begin{array}{l}16.1 \\
16.2 \\
16.5 \\
17.0\end{array}$ \\
\hline $\begin{array}{l}\text { Education of husbands } \\
\text { No education } \\
\text { Primary incomplete } \\
\text { Primary complete } \\
\text { Secondary and higher } \\
\text { education }\end{array}$ & $\begin{array}{c}15.3 \\
-- \\
-- \\
14.0\end{array}$ & $\begin{array}{l}17.0 \\
16.3 \\
15.9 \\
16.2\end{array}$ & $\begin{array}{c}15.5 \\
-- \\
16.8 \\
17.0\end{array}$ & $\begin{array}{l}16.5 \\
16.3 \\
16.2 \\
16.6\end{array}$ \\
\hline $\begin{array}{l}\text { Occupation of husbands } \\
\text { Manually } \\
\text { Not manually }\end{array}$ & $\begin{array}{l}15.3 \\
16.0\end{array}$ & $\begin{array}{l}16.1 \\
16.5\end{array}$ & $\begin{array}{l}17.5 \\
16.8\end{array}$ & $\begin{array}{l}16.3 \\
16.5\end{array}$ \\
\hline
\end{tabular}

In the context of Bangladesh, the head of a household as a rule is an adult man, no matter if he is the bread earner or not. If there is no adult male resident, a woman might be the head of the household. Female-headed households are usually single-parent households ${ }^{6}$. Adolescents from households headed by females have a lower mean age at first birth than adolescents from male-headed households. This may reflect that adolescents from single parents engage in marital union very early compared to their counterparts from families of married couples. Moslems seem to have the highest mean age at first birth (16.5 years) than the non-Muslims (15.5 years).

It can be seen from Table: 3 that adolescents with no education have a lower mean age at child bearing than those who did not complete primary education or completed primary or secondary education. This confirms the hypothesis that the higher the level of education, the higher the age at first child bearing. However, the low level of education is not the cause of early child bearing. Rather the coincidence of the two; and usually a characteristic of living in impoverished and rural environments. The reason why adolescents who have attended secondary school give first birth later can be easily understood. In Bangladeshi culture schools do not allow visible pregnant women or mothers to continue with their education. Furthermore, the possible reason, why those, who have completed primary education, give birth earlier than those with secondary education and above might be due to the absence of occupation or further education after five years in school. Most of those who leave primary schools get married that result in early births. Education of husband has no clear pattern on adolescent's age at first birth. Moreover, those respondents whose husbands were engaged not in manual works (Professional, serviceman, businessman etc.,) have highest mean age at first birth (16.5 years).

\section{Determinants of Adolescents Age at First Motherhood Multiple Linear Regression Analysis}

The analysis of adolescents show that each of the background characteristics including education, age at first marriage, religion, place of residence, occupation of husbands and current age tend to influence adolescent age at first birth. Here, the relationship between a combination of all these variables and age at first birth will be determined in a more complex way. The relationships 
found earlier between each of the background characteristics and age at first birth may be different when all the variables are combined. Normally, this comes about as a result of the interrelationship between the independent variables. This leads us to supplement bivariate analysis with multivariate analysis.

The background characteristics are the independent variables. The unit of analysis is ever given birth adolescent. For each background characteristic, dummy variables are created with one category being selected as the reference category. As such they are omitted from the equation. This type of regression is the one in which coefficients are compared. Regression results are shown in Table 4.

Table 4 shows the regression results estimating the effect of background variables on age at first birth of the adolescents. All variables included in the multiple regression analysis explain 62 percent variability in age at first birth of the adolescents. It means therefore that the available background variables have explained much of the variation in age at first birth and they play a significant role. For adolescents, current age is found to have positively related to age at first child bearing.

Education rises the age at first birth (Table 4). Adolescent women with no education have lower age at first birth where as secondary education raises adolescents' age at first birth. However, no significance impact of husband's education is observed. Again, the age at first marriage is positively related to age at first birth, that is the delayed marriage can delayed first birth.

Religion is also an important factor that affects age at first birth ${ }^{7}$. Non-Muslims generally had their first births earlier than Moslems. A non-Moslem adolescent tends to give birth 0.16 years earlier than Muslims adolescents (Table 4). Place of residence plays no significant role on age at first birth for adolescents. Adolescents whose husbands were not engaged in manual work tend to give birth 0.38 years later than those whose husbands were manual workers.

\section{Adolescent's Use of Contraceptives}

Concerns about the adverse consequences of early child bearing, and the risks of contracting sexually transmitted diseases have led to renewed interest in the contraceptive and sexual behavior of adolescents ${ }^{8}$. The fact that adolescents have an enormous impact on future population growth make an understanding of the extent to which young women are aware of and use contraceptives significant policy issue. This section will shed light on contraceptive use among adolescents.

Table 4: Regression results (unstandardised coefficients) of the Relationship between Adolescent's Age at First Birth and Some Selected Socio-economic Variables.

\begin{tabular}{|c|c|c|c|c|}
\hline Variable & Name & Variables & $\begin{array}{l}\text { Unstanderdized } \\
\text { coefficient }\end{array}$ & Standard error \\
\hline Current age & $15-19$ & Continuous & $0.366^{*}$ & 0.113 \\
\hline $\begin{array}{l}\text { Education of } \\
\text { respondents }\end{array}$ & $\begin{array}{l}\text { No education } \\
\text { Primary incomplete } \\
\text { Primary complete } \\
\text { Secondary and higher }\end{array}$ & $\begin{array}{l}\mathrm{RC} \\
\mathrm{E} 2 \\
\mathrm{E} 3 \\
\mathrm{E} 4\end{array}$ & $\begin{array}{c}0.853^{*} \\
1.192^{* *} \\
2.282^{* *}\end{array}$ & $\begin{array}{c}0.384 \\
0.286 \\
.279\end{array}$ \\
\hline $\begin{array}{l}\text { Education of } \\
\text { husbands }\end{array}$ & $\begin{array}{l}\text { No education } \\
\text { Primary incomplete } \\
\text { Primary complete } \\
\text { Secondary and higher }\end{array}$ & $\begin{array}{l}\mathrm{RC} \\
\mathrm{H} 2 \\
\mathrm{H} 3 \\
\mathrm{H} 4\end{array}$ & $\begin{array}{l}0.344 \\
0.021 \\
0.108\end{array}$ & $\begin{array}{l}0.368 \\
0.258 \\
0.244\end{array}$ \\
\hline Age at first marriage & $\begin{array}{l}>15 \\
15-17 \\
18-19\end{array}$ & $\begin{array}{l}\mathrm{RC} \\
\mathrm{A} 1 \\
\mathrm{~A} 2\end{array}$ & $\begin{array}{c}0.118 \\
3.046^{\star \star *}\end{array}$ & $\begin{array}{l}.0 .216 \\
0.519\end{array}$ \\
\hline Religion & $\begin{array}{l}\text { Muslims } \\
\text { Non-Muslims }\end{array}$ & $\begin{array}{l}\mathrm{RC} \\
\mathrm{R} 1\end{array}$ & -0.155 & 0.269 \\
\hline Place of residence & $\begin{array}{l}\text { Urban } \\
\text { Rural }\end{array}$ & $\begin{array}{l}\mathrm{RC} \\
\mathrm{P} 1\end{array}$ & -0.035 & 0.237 \\
\hline $\begin{array}{l}\text { Occupation of } \\
\text { husbands }\end{array}$ & $\begin{array}{l}\text { Manual } \\
\text { Not Manual }\end{array}$ & $\begin{array}{l}\mathrm{RC} \\
\mathrm{O} 2\end{array}$ & $0.384^{*}$ & 0.196 \\
\hline Constant & & & $11.500^{* *}$ & 2.042 \\
\hline
\end{tabular}

Note: $R C=$ Reference category. Adj. $R^{2}=.620$. Here ${ }^{* * *}{ }^{* *}$ and ${ }^{*}$ indicates $p<.001$ (highly significant), $p<.01$ (significant), $p<.05$ (less significant). 
Although contraceptive prevalence among currently married women of reproductive age is increasing rapidly in many developing countries, the rates have not yet reached those of developing countries. The level of contraceptive use in most developing countries is higher among women in their thirties and, typically, lowest among teenage women and women in their forties. Studies in developed and developing countries demonstrate that the behavioral patterns of contraceptive acceptance and use differ significantly between adolescents (females approximately 10-19 years of age) and adults (women

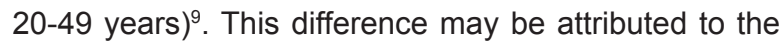
maturity, greater knowledge and experience of adults compared with adolescents.

Such considerations as desired family size and child-spacing influence contraceptive prevalence among married women at the individual level, while at the macro level, laws and regulations and culture are important factors that determine access to contraception ${ }^{10}$. Some laws relate specifically to female teenagers. Both married and unmarried adolescents face the added obstacles of legal or cultural restrictions, which limit their access to family planning services. However, unwanted pregnancies resulting from lack of contraceptive use have led to an increasing number of abortions among young women. In many parts of the world, despite the fact that young women are often denied access to legal abortion services, both the number and the proportion of abortions performed for young women have been increasing over time.

Aside from external influences at the socio-cultural and policy levels that affect an adolescent's contraceptive behavior, factors, which vary at the individual level, are also important, such as whether or not contraception occurs within a stable relationship, and whether or not either partner has had previous experience with contraception.

The average age at marriage (14.8 years) in Bangladesh remains one of the lowest in the world, a large proportion of the potential acceptors of contraception are married adolescents. The adolescent phase of human life is often termed as a very "demographically dense" phase because more demographic actions occur during these years than at any other stage of life. Unfortunately no exclusive and comprehensive study on the contraceptive behavior of married adolescents in Bangladesh has been undertaken; therefore, in view of the importance of this matter, an attempt has been made in this study to investigate their contraceptive behavior. In this section therefore, the unit of analysis are all adolescent women who are in marital union.

\section{Current Use of Contraception}

The term "current use" refers to the method that was being used by an individual client at the time of the survey. Thus, any respondent (or her spouse) using a family planning method at the time of survey was regarded as a current user.

Table 5 summarizes the current level of contraceptive use among the adolescents who were currently married. The results indicate that the contraceptive prevalence is about 56.7 per cent among adolescents. The 56.7 per cent CP (Contraceptive prevalence) can be broken down further as 54.7 per cent for modern methods and 2.0 per cent for traditional methods. Among individual methods, the pill accounted for the highest use (28.0 per cent), followed by the condom (22.6 per cent). IUDs, injection and others traditional contraceptives were the least commonly used methods among adolescents.

Table 5: Percentage of Adolescents who are currently using any Specific Methods.

\begin{tabular}{|l|c|c|}
\hline Contraceptive methods & $\begin{array}{c}\text { Percentage (\%) of adolescents } \\
\text { currently using contraceptives }\end{array}$ & No. of cases \\
\hline Any modern methods & 28.0 & 280 \\
Pill & 0.7 & 7 \\
IUD & 0.7 & 7 \\
Injections & 22.6 & 226 \\
Condom & 52.0 & 520 \\
Sub-total & & \\
\hline Any traditional methods & 2.7 & 27 \\
Safe period & 2.0 & 20 \\
Others & 4.7 & 47 \\
Sub-total & 56.7 & 567 \\
\hline Any method & 43.3 & 433 \\
\hline No method & 100.0 & 1000 \\
\hline Total & & \\
\hline
\end{tabular}




\section{Differential in Current Use of Contraception}

Table 6 shows the differential effect of some selected socio-economic and demographic variables on current use of contraception. The table shows that use of contraceptives tends to increase with increasing age of the adolescents. Educational levels are associated with contraceptives use. Our results express that current use of contraceptive methods is 43.8 percent among adolescent who have no education which rise to 46.2 percent among adolescents who did not complete primary education. Further it rises to 57.9 percent among adolescents who have completed primary education and reached to a high of 60.2 percent for those who have secondary level of education. However, educations of husband have no clear pattern on contraception use of the adolescence.

Table 6: Differentials in Current Use among Adolescents by Selected Demographic and Socio-economic Characteristics.

\begin{tabular}{|c|c|c|}
\hline Characteristics & No. of cases & $\begin{array}{l}\text { Number and Percentage of adolescents } \\
\text { currently using contraceptives }\end{array}$ \\
\hline $\begin{array}{l}\text { Age of respondents } \\
15 \\
16 \\
17 \\
18 \\
19 \\
15-19\end{array}$ & $\begin{array}{c}93 \\
153 \\
260 \\
187 \\
307 \\
1000\end{array}$ & $\begin{array}{l}43(45.5) \\
77(50.0) \\
138(52.8) \\
112(59.6) \\
197(63.9) \\
567(56.7)\end{array}$ \\
\hline $\begin{array}{l}\text { Respondent's education } \\
\text { No education } \\
\text { Primary incomplete } \\
\text { Primary complete } \\
\text { Secondary/higher }\end{array}$ & $\begin{array}{l}107 \\
86 \\
253 \\
554\end{array}$ & $\begin{array}{l}47(43.8) \\
40(46.2) \\
147(57.9) \\
333(60.2)\end{array}$ \\
\hline $\begin{array}{l}\text { Husband's education } \\
\text { No education } \\
\text { Primary incomplete } \\
\text { Primary complete } \\
\text { Higher }\end{array}$ & $\begin{array}{l}141 \\
73 \\
253 \\
533\end{array}$ & $\begin{array}{l}67(47.6) \\
53(72.7) \\
173(68.4) \\
274(51.3)\end{array}$ \\
\hline $\begin{array}{l}\text { Place of residence } \\
\text { Urban } \\
\text { Rural }\end{array}$ & $\begin{array}{l}220 \\
780\end{array}$ & $\begin{array}{l}133(60.6) \\
434(55.5)\end{array}$ \\
\hline $\begin{array}{l}\text { Religion } \\
\text { Muslims } \\
\text { Non-Muslims }\end{array}$ & $\begin{array}{c}973 \\
27\end{array}$ & $\begin{array}{l}560(57.5) \\
7(25.0)\end{array}$ \\
\hline $\begin{array}{l}\text { Husbands occupation } \\
\text { Manual } \\
\text { Not manual }\end{array}$ & $\begin{array}{l}540 \\
460\end{array}$ & $\begin{array}{l}273(50.6) \\
294(63.8)\end{array}$ \\
\hline $\begin{array}{l}\text { Age at first marriage } \\
<15 \\
15-16 \\
17+\end{array}$ & $\begin{array}{l}473 \\
300 \\
227\end{array}$ & $\begin{array}{l}293(62.0) \\
140(46.7) \\
134(58.8)\end{array}$ \\
\hline $\begin{array}{l}\text { Age at first birth } \\
<15 \\
15-16 \\
17+\end{array}$ & $\begin{array}{l}106 \\
140 \\
207\end{array}$ & $\begin{array}{c}60(56.3) \\
107(76.2) \\
154(74.2)\end{array}$ \\
\hline $\begin{array}{l}\text { Visits of family planning workers } \\
\text { Regularly } \\
\text { Irregularly }\end{array}$ & $\begin{array}{l}760 \\
240\end{array}$ & $\begin{array}{l}453(59.4) \\
114(47.2)\end{array}$ \\
\hline
\end{tabular}

(Value with parenthesis represents percentage) 
Table 7: Percentage of Adolescents Currently Using Contraception to Delay First Birth by Current Age.

\begin{tabular}{|c|c|c|c|c|c|}
\hline \multirow{2}{*}{$\begin{array}{l}\text { Current } \\
\text { age }\end{array}$} & \multirow{2}{*}{$\begin{array}{c}\text { Number and Percentage } \\
\text { of adolescents not using } \\
\text { contraception to delay first } \\
\text { birth }\end{array}$} & \multirow{2}{*}{$\begin{array}{l}\text { Number and Percentage } \\
\text { of adolescents currently } \\
\text { using contraception to } \\
\text { delay first birth }\end{array}$} & \multirow{2}{*}{$\begin{array}{c}\text { No. of } \\
\text { cases } \\
\text { (Not having } \\
\text { birth) }\end{array}$} & \multicolumn{2}{|c|}{ Method specific used } \\
\hline & & & & Modern & Traditional \\
\hline 15 & $46(63.6)$ & $27(36.4)$ & 73 & $20(75.0)$ & $7(25.0)$ \\
\hline 16 & $54(50.0)$ & $53(50.0)$ & 107 & $47(87.5)$ & $6(12.5)$ \\
\hline 17 & $100(53.6)$ & $87(46.4)$ & 187 & $67(76.9)$ & $20(23.1)$ \\
\hline 18 & $87(72.2)$ & $33(27.8)$ & 120 & $26(80.0)$ & $7(20.0)$ \\
\hline 19 & $47(77.8)$ & $13(22.2)$ & 60 & $6(50.0)$ & $7(50.0)$ \\
\hline $15-19$ & $334(61.0)$ & $213(39.0)$ & 547 & $166(78.1)$ & $47(21.9)$ \\
\hline
\end{tabular}

(Value with parenthesis represents percentage)

Table 8: Logistic regression of Current Contraceptive Use among Adolescents on Some Selected Socio-demographic characteristics.

\begin{tabular}{|c|c|c|c|}
\hline Characteristics & Co-efficient (ß) & S.E & $\begin{array}{l}\text { Odds Ratio } \\
{[E x p(\beta)]}\end{array}$ \\
\hline $\begin{array}{l}\text { Education of respondents- } \\
\text { No education (Ref:) } \\
\text { Incomplete primary education } \\
\text { Completed primary education } \\
\text { Secondary and higher school }\end{array}$ & $\begin{array}{c}\ldots \\
0.270 \\
0.340 \\
0.650\end{array}$ & $\begin{array}{c}\ldots \\
0.466 \\
0.554 \\
0.613\end{array}$ & $\begin{array}{c}1.000 \\
1.074 \\
1.405^{\star} \\
1.915^{\star *}\end{array}$ \\
\hline $\begin{array}{l}\text { Education of husbands- } \\
\text { No education (Ref:) } \\
\text { Incomplete primary education } \\
\text { Completed primary education } \\
\text { Secondary and higher }\end{array}$ & $\begin{array}{c}\ldots \\
2.624 \\
0.468 \\
-0.359\end{array}$ & $\begin{array}{c}\ldots \\
0.323 \\
0.792 \\
0.787\end{array}$ & $\begin{array}{c}1.000 \\
13.792 \\
1.597 \\
0.698\end{array}$ \\
\hline $\begin{array}{l}\text { Religion- } \\
\text { Muslims (Ref:) } \\
\text { Non- Muslims }\end{array}$ & $\begin{array}{c}\ldots \\
-1.254 \\
\end{array}$ & $\begin{array}{c}\ldots \\
1.268\end{array}$ & $\begin{array}{l}1.000 \\
0.285 \\
\end{array}$ \\
\hline $\begin{array}{l}\text { Residence- } \\
\text { Rural (Ref:) } \\
\text { Urban }\end{array}$ & 0.890 & $\begin{array}{c}\ldots \\
0.465\end{array}$ & $\begin{array}{l}1.000 \\
2.436^{*}\end{array}$ \\
\hline
\end{tabular}

Here (Ref) =reference category, and *, ** and *** indicates $p<0.05, p<0.01$ and $p<0.001$

Adolescents from urban areas show higher use of contraception (60.6 percent). Muslims adolescents (57.5 percent) were consistently more frequent users of contraceptive than non-Muslim (25.0 percent). Nonmanual working husbands have a positive role on contraceptive use (Table 6). However, the relationship between age at first marriage and first birth with contraceptives use has no clear pattern. Contraceptive use rate increases with visits of family planning workers. This indicates a positive relationship between visits of family planning workers and contraceptive use.

\section{Adolescents Use of Contraception to Delay First Birth}

From the above discussion we see that contraceptive use among adolescence in my study area is still low. However, our interest is to investigate those adolescents who use contraceptive to delay first birth. Since the survey data collect no information directly to find such information, further we consider those adolescent who have no child at the time of the survey but currently using contraception, might give us such information. Table 7 shows the percentage of the adolescents who have no children but currently using contraception to delay birth.

From the above table we see that about 39.0 percent adolescents used contraceptive to delay first birth and most of them used modern method (78.1 percent) rather than traditional method (21.9 percent) to delay birth.

\section{Factors Affecting Adolescent's Current Use of Contraception: A Logistic Regression Analysis}

Logistic regression technique used here to identify the factors affecting the contraceptive use rate among adolescents. Current use of contraception was made the 
dependent variable, which we dichotomized by assigning the value 1 , if the respondent was using any method of contraception and 0 , if she was not using any method. From the results of the logistic regression analysis (Table 8) education continues to have very strong and positive independent effect on contraception with the likelihood of current use increasing significantly as the women's education increases. Adolescents not completing primary education were 1.074 times more likely to use contraception than adolescents with no education. The odds ratio increases as the women's educational level increases. However, partner's education has very low impact (insignificant) on contraception use.

Non-Muslims adolescents were 0.28 times less likely to use contraception than the Muslims adolescents. Place of residence has also a net significant effect on current use of contraception. Urban adolescents were 2.4 times more likely to use contraception than the rural counterpart. Husband's manual works comprises 0.60 times less use of contraception. The analysis further indicates that frequency of visits by family planning workers is significantly and positively related to current use of a contraceptive method among adolescent mothers. Adolescent mothers were more likely to use family planning methods when family planning workers visit them regularly. In view of the likelihood that visits by family planning workers can motivate adolescents by providing them with counseling on family planning methods and by providing family planning services and disseminating supplies to achieve their widespread availability. Current age of adolescents is highly related to contraceptives use. It is seen that contraceptive use increase as the age of adolescents increases.

\section{Conclusions and Policy Implications}

We have observed that adolescents engage in marital union at early ages. Mean age at first marriage ranges from 13.7 years to 15.1 years. Mean age at first birth of the adolescents was found to be 16.4 years. In this study we found that literate women had a higher likelihood of delaying birth. Literacy rises age at first birth for adolescents. This may be a result of educated women delaying their marriage and so to have a tendency to delay birth. An urban woman had a higher likelihood of delaying birth than a rural woman. Altogether urban women were more likely to delay the birth than their rural counterparts. This means that women from a rural background have a higher risk of having the first birth early than those with urban backgrounds. Non-Moslem adolescents were found in this study to be more likely to start giving birth earlier than Muslims. It was found that adolescents whose husband engaged in manual work tends gave birth earlier than those whose husbands were not manual workers. In this study a limited attempt has been made to investigate some important aspects of contraceptive behavior among adolescent. The analysis shows that, use of contraceptive among the adolescents is still very low. Slightly 56.7 per cent of the married adolescents currently used any method of contraception. Low contraceptive use among married adolescents may be attributed to several socioeconomic and cultural factors, such as education, religiosity, social conservativeness, husband-wife communication, occupation and economic condition ${ }^{11}$. In addition, adolescents may face greater difficulties in obtaining contraceptive supplies and they may lack proper knowledge of the use of modern contraceptive methods.

The results of our study indicate that due to widespread publicity about modern contraceptive methods most adolescents use modern contraceptive methods and traditional methods account for only a small proportion of contraceptive use among adolescents. Programme managers, therefore, should give due importance to this fact. Among the factors determining contraceptive use among adolescents, education appears to be the most significant; education is positively associated with contraceptive use. Evidence suggests that education not only increases awareness of social mobility and creates a new outlook and rationalism among couples, but also reduces desired family size by raising desired living standards, bringing about a better understanding of the reproductive process, better knowledge about health care and access to modern and effective means of birth control. Adolescents residing in urban areas were more aware, and use contraceptives to a higher degree than those in rural areas. This might be due to the fact that health facilities are more concentrated in urban areas than in rural areas. Several kinds of mass media too are concentrated in urban areas. Muslim adolescent used contraceptives more than the non-Muslim religious affiliates Adolescent used of contraceptives did not show any relationship with age at first marriage and birth.

This study therefore concludes that: 1) frequent visits by family planning workers greatly affect the contraceptive use rate among adolescents. Frequent visits by family planning workers and their counseling about family planning methods help to motivate adolescents to accept family planning methods and use them effectively; 2) early childbearing can be postponed by delaying early marriage. The legal age at marriage in Bangladesh is 18, but to reduce the risk to the mother, couples should delay the first pregnancy until 
the wife is at least 20 years old. Unfortunately, most of our respondents get married during their adolescence. Therefore, Government of Bangladesh has to take initial steps to strictly prohibit the early marriage with the proper application of existing law that would directly or indirectly rise the age at first birth; 3) this study indicates that providing secondary level or higher education to all women will help reduce the proportions of women marrying and giving birth while still in their teens. However, it is difficult to provide a secondary level of education to a large segment of population in a short period of time. School-based reproductive health programmes need to be introduced specially in rural areas, perhaps during the last years of primary school, considering that only a small proportion of rural girls attend secondary level schools; 4) in order to reduce the rate of early childbearing, adolescents, their parents and community should be made more aware of the negative health, social and economic consequences of early marriage and early childbearing. Such awareness could be created through social mobilization and information, education and communication campaigns; 5) provide adolescents with information on the availability of family planning methods and their effectiveness; 6 ) programmes that encourage postponement of first birth after marriage through adoption of temporary contraceptive methods should be considered seriously; 7) providing appropriate, accurate sexual and reproductive health education for young people, both in- and out-of-school, that respond to young peoples' particular needs; help them make informed decisions about sexuality and negotiate safer sex; and emphasize the prevention of unwanted pregnancy, unsafe abortion and STDs.

Last but not least, no policy can be successful unless implemented in every society from the grass-root to the national level. Hope, our government's policy makers will be helpful enough to review our recommendation.

Acknowledgement: I would like to thank the adolescent women and other research assistants who participated in this study.

\section{Conflict of Interest: Nil.}

Funding: The study was conducted as part of the project entitled "strengthening the Department of population Science and Human Resource Development", a collaboration between the Department of Population science and Human Resource Development, Rajshahi University and the UNFPA Bangladesh.

\section{References}

1. Bangladesh Bureau of Statistics (BBS). Bangladesh Population Census, 1991. Dhaka, Bangladesh, Bureau of Statistics, Statistics Division, Ministry of Planning, 1993.

2. Bangladesh Bureau of Statistics (BBS). Bangladesh Population Census, 2001. Dhaka, Bangladesh, Bureau of Statistics, Statistics Division, Ministry of Planning, 2003.

3. NIPORT. Bangladesh Demographic and Health Survey, 1999-2000. National Institute of Population Research and Training. Dhaka, Bangladesh. Mitra Associates and Macro international Inc. Calverton. Maryland, USA, 1999.

4. Kamal, N. and A. Slogett. The influence of religiosity, mobility and decision-making on contraceptive use. Secondary Analysis, BFS 89, NIPORT, Dhaka, 1993

5. M. Mazharul Islam and Mamun Mahmud. Contraception among adolescents in Bangladesh. Asia Pacific Population Journal, Vol.10, No.1 (1995), pp.21-35

6. Renis, K.I. The impact of proximate determinants of fertility.. Evaluating Bongarasts and Hoberaft and Little's Methods of estimation, Population Studies. Vol.46.pp 309-326.

7. Gage, A.J. An assessment of the quality of data on age at first union, first birth, and first sexual intercourse for Phase II of the Demographic and Health Surveys Program. Occasional Papers. Calverton, Maryland, Macro International Inc, 1995.

8. Ngalinda, I. Age at first birth, fertility and contraception in Tanzania, Ph.D. Thesis, University of Berlin, 1998.

9. Trussel, J. Age at first marriage and first birth, Population Report, 1989, 4(1): 126-193.

10. Ullah and Chakraborty. Socio-cultural factors affecting practice of contraception in metropolitan urban areas of Bangladesh. Paper presented at the seminar of Fertility of Bangladesh held at Coxe's Bazar, 1993 p.op.21-23

11. Mary, M. and Nerru, G. Trends and differentials in age at first birth in sub-Saharan Africa; Demographic and Health Research Division ORC, Macro International Calverton, USA, 2001. 